\title{
Identification of Main Commodities as Regional Development Bondowoso Regency
}

\author{
Nevy Farista Aristin \\ Lambung Mangkurat University \\ Corresponding Email: nevyfarista@unlam.ac.id \\ Ellyn Normelani \\ Lambung Mangkurat University \\ Agus Purnomo \\ State University of Malang
}

\begin{abstract}
Bondowoso dominated by wetland agriculture and dryland agriculture has a leading sectors that could be developed in addition to cassava iconic regency. To overcome these problems it is necessary to identify the leading sectors of agriculture in the regency that can later be developed into potential winning. The method used is the institutional survey method. The technique used in this research is purposive method of selection of research sites in accordance with the purpose of research. This research was conducted in the Bondowoso regency and the analysis unit of research are dominated by agricultural land dry and wet agricultural land, ie 17 districts out of 23 districts. The analysis used in this research is Location Quotient (LQ). The results showed that the potential of leading commodity agricultural sector the highest in Pujer District with superior sector mustard, Tlogosari District the leading sectors of pumpkin, Bondowoso District with superior sector green beans, Curahdami District with leading sectors onion, and Prajekan District with superior sector plants sweet potato. It will Bondowoso 5 districts can develop as centers of crop specific seed so that later can improve the community economy regency. It continues to be improved in its development as agropolitan and as one of the buffer zone of people's food needs regency.
\end{abstract}

Keywords-Commodities, agriculture, regional development

\section{INTRODUCTION}

Bondowoso is one of the regencies in the province of East Java. The regency has several missions, one of which is to optimize the utilization of space in the cultivated area through improving the productivity of land and new innovations in agriculture. Land use in Bondowoso regency in 2007 was largely dominated by agricultural land, protected forests, wetlands and agriculture (paddy) (Aristin, 2015).

Klosterman (1990) states that "information about the future population of an area is not complete without understanding the parallel nature of the local economy which will also affect the future development of the region". This means that the economy of the region is very important in the development of the region so that each region should be aware of local economic sectors. In this case means the orientation basis for the development of the leading sectors of each region, especially in anticipation of the development of long term and short term in planning the development of a region. Therefore, the Government intervened carefully the development process of the region through regional planning, one of which with a division structure.

The development of an area closely related to optimal utilization of the potential and hence the birth of regional differences in the various levels. Zaldi (2001) states that "the direction of development of regions using sector analysis that has great potential to spur the development of a region".

One of the policies for regional development, namely by setting a particular sub-districts are prioritized to be developed based on the characteristics and potential of the region be expected to create a growth center of the regency were able to generate growth in the area itself and the area around the center of growth (Haryanto, 2006). Thus the center of each region growth will not occur simultaneously. It is because the development of the region will depend on the locations of natural resources and other location advantages. Each region must know the potential of existing natural resources in the region to be developed optimally.

The leading sectors of each region greatly affect the improvement of regional development. With the leading sectors that will be known to potential areas that could be used to implement a policy strategy and a sustainability plan area.

Based on the above, the problem in this research is Bondowoso regency have a commodity that is only focused on cassava plants. Based on the existing land use, Bondowoso regency is not only dominated by dry land farming but also by agricultural wetlands. To overcome these problems it is necessary to identify what the sector can be seeded according to the characteristics and potential of each region. The leading sectors will be featured each commodities districts in regency. This, in turn, can increase the level of community economy regency. 


\section{METHOD}

This research method using institutional survey. Institutional survey method is a method of research that examines all members of the population is based on data obtained from the relevant institutions. This study was conducted in 17 districts dominated by the function of cultivated area in the regency. The required data are secondary data obtained from the relevant agencies. Processing data using Microsoft Excel and data processing spatial with ArcView program. Analysis of the data used in this study is an analysis Location Quotient. Analysis of Location Quotient is an analysis that compares the potential across sectors and across regions.

Muta'ali (2015) states that “Location Quotient analysis techniques is used to determine what leading sectors that can export (out of area) in the economy of a region, which is an indicator that shows the strength of the role of a sector in a region compared to the same sector role in the regional benchmark".

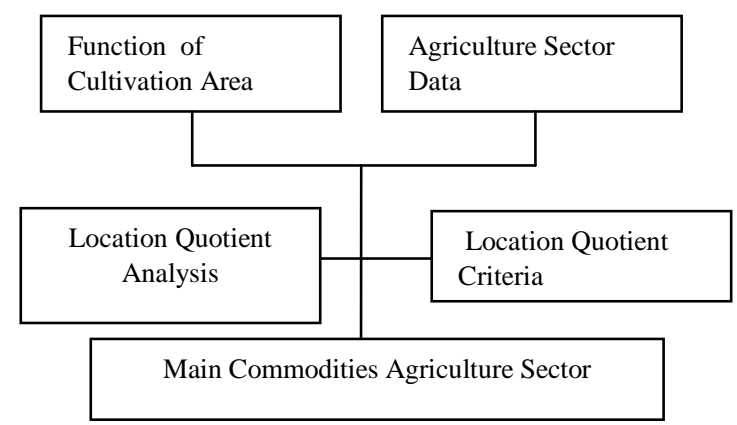

Fig 1. Flowchart of Research

\section{FINDING AND DISCUSSION}

Agriculture is one of the main sectors were very influential in boosting the economy in the regency. Bondowoso in terms of land use is dominated by agricultural land both dryland and wetland. For this reason cultivation area in the regency is still oriented on agropolitan.

The agricultural sector has excellent potential levels or different classes ranging from low to high. The higher the class of the excellent potential agricultural sector, the higher the crop will serve as the pre-eminent sector (a sector basis). Glasson (1990) states that "Sector bases are sectors that export goods and services to places outside the limits of public economic concerned over input their goods and services to people who come from outside the borders of the community's economy are concerned ".
TABLE 1. Class Potential COMMODITy AgRiCulture SECTOR IN 2011 EACH SUB-DISTRICT IN THE REGENCY

\begin{tabular}{|l|l|r|c|c|}
\hline No. & Districts & Re-scaling & Klas & Ket. \\
\hline 1 & Headstone & 71.51 & II & moderate \\
\hline 2 & Grujugan & 54.04 & II & moderate \\
\hline 3 & Tamanan & 64.13 & II & moderate \\
\hline 4 & Jambesari & 64.57 & II & moderate \\
\hline 5 & Pujer & 91.45 & I & high \\
\hline 6 & Tlogosari & 77.11 & I & high \\
\hline 7 & Sukosari & 71.15 & II & moderate \\
\hline 8 & Tapen & 64.31 & II & moderate \\
\hline 9 & Wonosari & 66.80 & II & moderate \\
\hline 10 & Tenggarang & 51.48 & III & low \\
\hline 11 & Bondowoso & 100.00 & I & high \\
\hline 12 & Curahdami & 77.81 & I & high \\
\hline 13 & Wringin & 0.00 & III & low \\
\hline 14 & Tegalampel & 57.03 & II & moderate \\
\hline 15 & Parks Krocok & 48.93 & III & low \\
\hline 16 & Klabang & 61.25 & II & Moderate \\
\hline 17 & Prajekan & 81.81 & I & High \\
\hline
\end{tabular}

The class excellent potential agricultural sector in each district Bondowoso Regency calculated using rescaling the data. Rescalling this data is to change the data back to a certain scale. The results are presented in the table rescalling class agricultural sector potential winning every district in the regency as follows.

From the table above it is known that the District Pujer (91.45), District Tlogosari (77.11), District of Bondowoso (100.00), District Curahdami (77.81), and the District Prajekan (81.81) has the class of the excellent potential of agriculture the highest compared to other districts in regency. Map class potential of the agricultural sector featured every district in the regency as follows (Fig. 2).

The results of the analysis of Location Quotient for the main commodity of agriculture sector every district in the regency as follows.

TABLE 2. Distribution Of Agricultural COMMODItIES SECTOR Most EXCELLENT YEAR 2011 EACH SUB-DISTRICT IN THE REGENCY

\begin{tabular}{|l|l|l|c|}
\hline No. & \multicolumn{1}{|c|}{ Districts } & \multicolumn{1}{|c|}{$\begin{array}{c}\text { Agricultural } \\
\text { Commodities }\end{array}$} & $\begin{array}{c}\text { LQ } \\
\text { Agriculture } \\
\text { sector }\end{array}$ \\
\hline 1 & Wringin & Cassava & 6.95 \\
\hline 2 & Tamankrocok & Green beans & 7,13 \\
\hline 3 & Tegalampel & Sweet potato & 3.41 \\
\hline 4 & Bondowoso & Green beans & 3.14 \\
\hline 5 & Curahdami & Red onion & 6.88 \\
\hline 6 & Grujugan & Red onion & 5.81 \\
\hline 7 & Headstone & Red onion & 3.73 \\
\hline 8 & Tamanan & Sawi & 2,46 \\
\hline 9 & Jambesari & Sawi & 1.86 \\
\hline 10 & Pujer & Sawi & 2.73 \\
\hline 11 & Tlogosari & Chayote & 14.89 \\
\hline 12 & Tenggarang & Soy & 2.82 \\
\hline 13 & Wonosari & Peanuts & 1.59 \\
\hline 14 & Tapen & Corn & 2.17 \\
\hline 15 & Klabang & Corn & 2.47 \\
\hline 16 & Prajekan & Sweet potato & 4.15 \\
\hline 17 & Sukosari & Cabbage & 15.85 \\
\hline
\end{tabular}

Source: Data Processing, 2012 
Based on the above table, it can be seen that most of the districts in the regency have the leading commodity distribution of the agricultural sector in the form of dry land crops such as corn, sweet potatoes, soybeans, peanuts, cassava, onion. For the agricultural sector leading commodity wetlands (paddy), among others, vegetables such as cabbage, squash, cabbage. This is due to factors topography, soil type, and the same climate and suitable in the regency.

Muta'ali (2015) featured a commodity is a product of sectoral or economic activities that serve both the domestic market as well as markets outside the region and particularly the export market.

Competitive commodities have characteristics include:

- have high production and dominant

- The rate of growth of production and high productivity

- absorb relatively large workforce

- connection or multiplier impact of high commodity between both forward and backward
- able to create high added value

- orientated serve markets outside its territory.

With known of the class potential winning and leading commodity it can be seen that there are some Subdistrict that has the basic sector (seed) and the leading commodity agriculture include the Subdistrict Pujer with superior sector mustard, Subdistrict Tlogosari with crops of squash, Subdistrict Bondowoso plant green beans, Subdistrict Curahdami with onion plants, and Subdistrict Prajekan with sweet potato crops.Five Subdistrict can be developed into agropolitan with the advantages of the agriculture sector basis. This is because the class has excellent potential and high commodity that can be developed and meet the needs of both the region itself and outside the region.

According to Glasson (1974), more and more sectors of the base in the region will increase revenue flows to the region, increasing the demand for goods and services in it, and give rise to increase in the volume of the non-base.

The superior agricultural region is an area that has potential superior agricultural sector are being developed to improve the economy of a region.

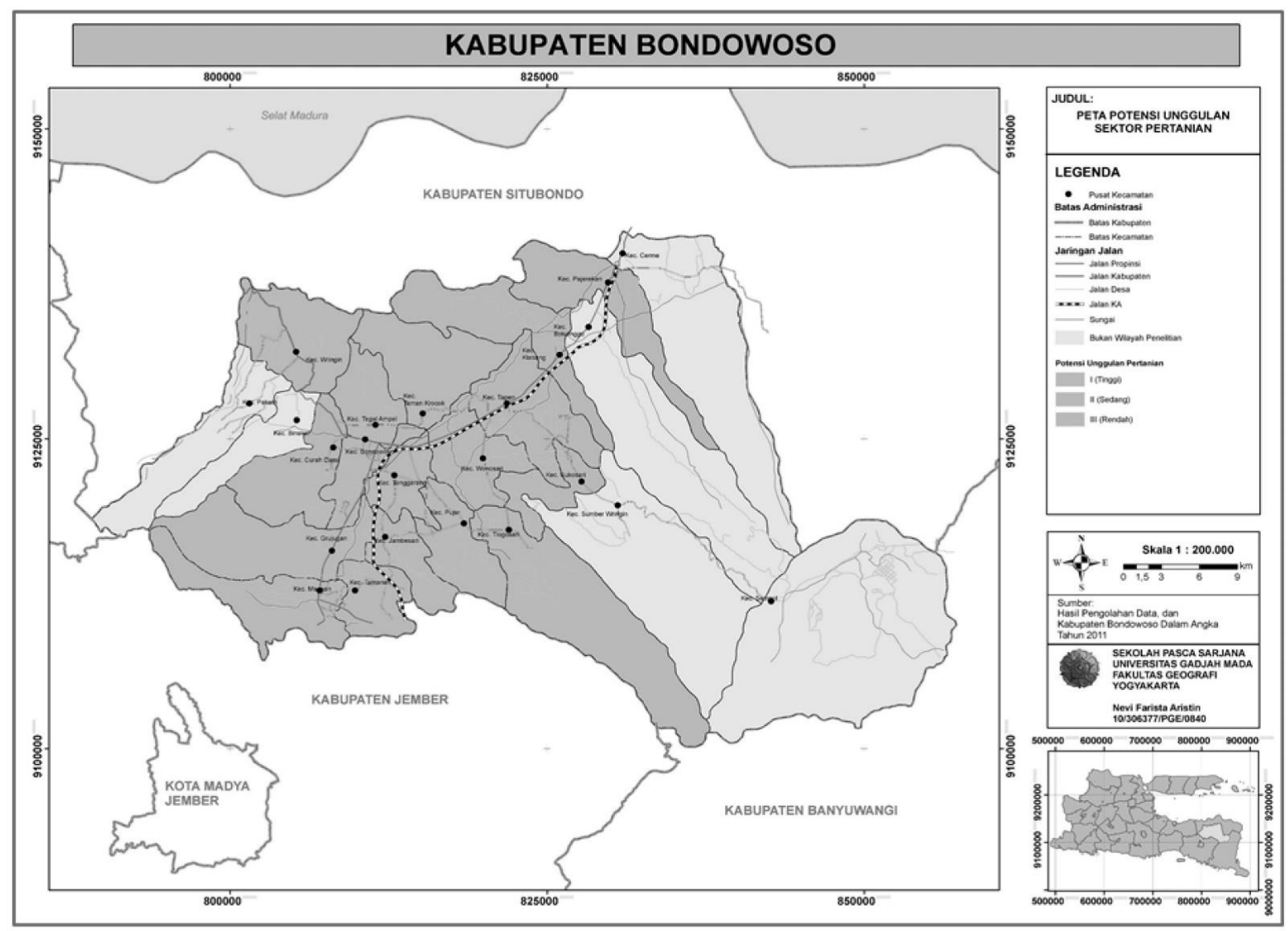

Fig.. 2. Map of Agricultural Commodities Sector Each sub-district in the regency 
In accordance with one mission of the regency that optimizes space utilization in the cultivation area through improving the productivity of land and new innovations in agriculture.

Undang-undang No. 262007 on Spatial Planning, Agropolitan is a region consisting of one or more centers in rural areas as agricultural production systems and management of certain natural resources which are indicated by the presence of functional interrelationships and hirakhi spatial unit settlement system and the system agribusiness (Article 1, Paragraph 24). Broadly speaking agropolitan need:

- The existence of the leading sectors that can be utilized in moving the agropolitan

- Areas that can be utilized to develop the seed sector (a sector basis).

\section{CONCLUSION}

Land use Bondowoso dominated by agricultural land both dryland and wetland have excellent potential classes, namely high grade, medium grade and low grade. High-grade potential spread in Subdistrict Pujer (91.45), Subdistrict Tlogosari (77.11), Subdistrict Bondowoso (100.00), Subdistrict Prajekan (77.81), and Subdistrict Curahdami (81.81).

The distribution of leading commodity agricultural sector in the form of dry land crops such as corn, sweet potatoes, soybeans, peanuts, cassava, onion. For the agricultural sector leading commodity wetlands (paddy), among others, vegetables such as cabbage, squash, cabbage.

With unknown potential winning their class and competitive commodities it can be seen that there are five districts that have the basic sector (seed) and superior agricultural commodities that can then be redirected to be developed as agropolitan regency. The Subdistrict of among others the Subdistrict Pujer with mustard seed sector, Subdistrict Tlogosari with crops of squash, Subdistrict Bondowoso to plant green beans, Subdistrict Curahdami with onion plants, and Subdistrict Prajekan with sweet potato crops.

\section{REFERENCES}

[1] Aristin, Nevy Farista, 2015, “Analisis Fungsi Kawasan Di Kabupaten Bondowoso", Jurnal Pendidikan Geografi, 39-45.

[2] Glasson, John, 1990, "Pengantar Perencanaan Regional, Terjemahan Paul Sitohang", Jakarta: LPFEUI.

[3] Glasson, John, 1974, "An Introducing to Regional Planning", Hutchinson of London.

[4] Haryanto, Asep, 2006, "Percepatan Pengembangan Wilayah Melalui Strategi Implementasi Wilayah Pengembangan (WP) dan Hirarki KotaKota (Studi Kasus: Kabupaten Subang)”, Jurnal PWK Unisba, Halaman 21-51.

[5] Klosterman, Richard E, 1990, "Community and Analysis Planning Techniques", Rowmand and Littlefield Publishers, Inc. Savage, Maryland. See Chapters 9-13.
[6] Muta'ali, Luthfi, 2015, “Teknik Analisis Regional Untuk Perencanaan Wilayah, Tata Ruang dan Lingkungan”, Yogyakarta: Badan Penerbit Fakultas Geografi UGM.

[7] Undang-Undang Nomor 26 Tahun 2007 tentang Penataan Ruang.

[8] Zaldi, Desmora, 2001, Alternatif Arahan Pengembangan Wilayah Kabupaten/Kota Propinsi Sumatra Barat. Skripsi Sarjana, Yogyakarta: Fakultas Geografi UGM 